\title{
Impacts of global climate change mitigation scenarios on forests and harvesting in Sweden
}

\begin{tabular}{|c|c|}
\hline Journal: & Canadian Journal of Forest Research \\
\hline Manuscript ID & cjfr-2016-0122.R1 \\
\hline Manuscript Type: & Article \\
\hline Date Submitted by the Author: & $\mathrm{n} / \mathrm{a}$ \\
\hline Complete List of Authors: & $\begin{array}{l}\text { Nordström, Eva-Maria; Swedish University of Agricultural Sciences, } \\
\text { Forsell, Niklas; IIASA, ESM } \\
\text { Lundström, Anders; Swedish University of Agricultural Sciences, } \\
\text { Department of Forest Resource Management } \\
\text { Korosuo, Anu; International Institute for Applied Systems Analysis (IIASA), } \\
\text { Ecosystem Services and Management Program } \\
\text { Bergh, Johan ; Linnaeus University } \\
\text { Havlík, Petr; International Institute for Applied Systems Analysis (IIASA), } \\
\text { Ecosystem Services and Management Program } \\
\text { Kraxner, Florian; International Institute for Applied Systems Analysis, } \\
\text { Frank, Stefan; International Institute for Applied Systems Analysis (IIASA), } \\
\text { Ecosystems Services and Management Program } \\
\text { Fricko, Oliver; International Institute for Applied Systems Analysis (IIASA), } \\
\text { Energy Program } \\
\text { Lundmark, Tomas ; Swedish University of Agricultural Scien, } \\
\text { Nordin, Annika; Swedish University of Agricultural Sciences, Department of } \\
\text { Forest Genetics and Plant Physiology, Umeå Plant Science Centre }\end{array}$ \\
\hline Keyword: & $\begin{array}{l}\text { forest impact analysis, forest product demand, scenario analysis, Swedish } \\
\text { NFI, wood supply potential }\end{array}$ \\
\hline
\end{tabular}

\section{SCHOLARONE}




\section{Impacts of global climate change mitigation scenarios on forests and}

\section{2 harvesting in Sweden}

3 Eva-Maria Nordström ${ }^{1,2, *}$, Nicklas Forsell ${ }^{2}$, Anders Lundström $^{1}$, Anu Korosuo ${ }^{2}$, Johan Bergh ${ }^{3}$,

4 Petr Havlík ${ }^{2}$, Florian Kraxner ${ }^{2}$, Stefan Frank ${ }^{2}$, Oliver Fricko ${ }^{4}$, Tomas Lundmark ${ }^{5}$, Annika

$5 \operatorname{Nordin}^{6}$

$6 \quad{ }^{1}$ Department of Forest Resource Management, Swedish University of Agricultural Sciences

7 (SLU), SE-901 83 Umeå, Sweden. Email addresses: eva-maria.nordstrom@slu.se (Eva-Maria

8 Nordström), anders.lundstrom@slu.se (Anders Lundström).

$9 \quad{ }^{2}$ Ecosystem Services and Management Program, International Institute for Applied Systems

10 Analysis (IIASA), Schlossplatz 1, A-2361 Laxenburg, Austria. Email addresses:

11 nordstr@iiasa.ac.at (Eva-Maria Nordström), forsell@iiasa.ac.at (Nicklas Forsell),

12 korosuo@iiasa.ac.at (Anu Korosuo), havlikpt@iiasa.ac.at (Petr Havlík), kraxner@iiasa.ac.at

13 (Florian Kraxner), frank@iiasa.ac.at (Stefan Frank).

$14{ }^{3}$ Department of Forestry and Wood Technology, Linnaeus University, SE-351 95 Växjö,

15 Sweden. Email address: johan.bergh@lnu.se (Johan Bergh).

$16{ }^{4}$ Energy Program, International Institute for Applied Systems Analysis (IIASA), Schlossplatz 1, 17 A-2361 Laxenburg, Austria. Email address: fricko@iiasa.ac.at (Oliver Fricko)

$18{ }^{5}$ Department of Forest Ecology and Management, Swedish University of Agricultural Sciences

19 (SLU), SE-901 83 Umeå, Sweden. Email address: tomas.lundmark@slu.se (Tomas Lundmark). 
$20{ }^{6}$ Department of Forest Genetics and Plant Physiology, Swedish University of Agricultural

21 Sciences (SLU), SE-901 83 Umeå, Sweden. Email address: annika.nordin@slu.se (Annika

22 Nordin).

$23{ }^{*}$ Corresponding author. Address: Department of Forest Resource Management, Swedish

24 University of Agricultural Sciences (SLU), SE-901 83 Umeå, Sweden. Telephone: +46 (0)90

25 7868258. Fax: +46 (0)90 7868125. Email address: eva-maria.nordstrom@slu.se 


\section{Abstract}

27 Under climate change, the importance of biomass resources is likely to increase and new

28 approaches are needed to analyze future material and energy use of biomass globally and locally.

29 Using Sweden as an example, we present an approach that combines global and national land-

30 use and forest models to analyze impacts of climate change mitigation ambitions on forest

31 management and harvesting in a specific country. National forest impact analyses in Sweden

32 have traditionally focused on supply potential with little reference to international market

33 developments. In this study, we use the global greenhouse gas concentration scenarios from the

34 Intergovernmental Panel for Climate Change to estimate global biomass demand, and assess

35 potential implications on harvesting and biodiversity in Sweden. The results show that the short-

36 term demand for wood is close to the full harvesting potential in Sweden in all scenarios. Under

37 high bioenergy demand, harvest levels are projected to stay high over a longer time and

38 particularly impact the harvest levels of pulpwood. The area of old forest in the managed

39 landscape may decrease. The study highlights the importance of global scenarios when

40 discussing national level analysis, and pinpoints trade-offs that policy making in Sweden may

41 need to tackle in the near future.

43 Keywords: Forest impact analysis, forest product demand, scenario analysis, Swedish NFI, 44 wood supply potential 


\section{Introduction}

46 Forests have an important role in climate change mitigation, both as a carbon sink and for

47 production of renewable materials and energy (IPCC 2014b). Bioenergy is an important energy

48 source for replacing fossil fuels, and biomass from forests is seen as the main potential feedstock

49 for bioenergy in the future in many projections (GEA 2012; IEA 2015). However, assessments of

50 the potential for bioenergy should include analysis of consequences on biodiversity and other

51 uses of forests and biomass in order to provide comprehensive and useful policy support

52 (Berndes et al. 2003). The demand for wood products and bioenergy is increasingly global

53 through international trade and various emission trading schemes, while the supply - forest

54 biomass - is produced locally. The local level is where resources are limited, and where the

55 trade-offs of increased biomass demand and increased timber harvests are faced at first, e.g.,

56 negative effects on other ecosystem services, decline of biodiversity, and land-use conflicts.

57 Thus, a multi-level perspective that considers the global demand on a local scale is complex but

58 critical if we want to address questions concerning the role and state of forests and forestry in the

59 future.

60 An appropriate basis for global modeling is the new matrix framework structure, set up by the

61 fifth Assessment Report of the Intergovernmental Panel on Climate Change (IPCC), which

62 allows for a direct and interlinked global analysis of climate change impacts and mitigation

63 options. The new matrix framework is constructed through a combination of two sets of

64 independent scenarios: the four Representative Concentration Pathways (RCPs) corresponding to

65 different levels of radiative forcing on one axis, and Shared Socio-economic Pathways (SSPs)

66 that express the development of socioeconomic drivers on the other axis (IPCC 2014a;

67 IPCC2014b; IPCC 2013; van Vuuren et al. 2014; van Vuuren et al. 2011). A recent publication 
68 by Fricko et al. (2016) explores the set of energy sources used under combinations of RCPs and

69 SSPs, highlighting the increased pressure on agricultural production and land use under more

70 stringent climate policies, and an increased global demand for forest biomass. In their study, the

71 demand for industrial roundwood doubles by 2100 under a scenario of stringent climate

72 mitigation (RCP2.6) combined with midway socio-economic development (SSP2), with half of

73 this biomass being harvested in the northern hemisphere.

74 Other than the global study of Fricko et al. (2016), to our knowledge there are no prior studies

75 that investigate how the SSPs and RCPs affect demand for specifically forest biomass. However,

76 there are studies based on other climate change scenarios, and Latta et al. (2013) and Toppinen

77 and Kuuluvainen (2010) give overviews of forest sector models that can be used to project wood

78 demand changes under different scenarios. Raunikar et al. (2010) used the Global Forest

79 Products Model (GFPM) to study the possible global implications of climate mitigation scenarios

80 of the previous IPCC (fourth) assessment report on wood and forests. Their analysis projects up

81 to a six-fold increase in the demand for energy wood already by 2060. The same scenarios were

82 investigated also by Nepal et al. (2012), who estimated up to 16-fold increase of wood energy

83 production in the United States alone by 2060, given the assumptions of rapid economic growth

84 described in the A1B scenario. The results varied between regions, and emphasized the

85 dependence of the scenario outcome on the current growing stock that is very different in

86 different parts of the country. Kallio et al. (2016) examine the effects of EU bioenergy policies

87 on Finnish forests. Modeling the EU forest biomass demand's impact on Finland with the EU-

88 wide Finnish forest sector model, SF-GTM, and further elaborating the results with the national

89 MELA model, they found that the harvests in Finland would increase between 19\% and 28\%

90 from 2010 to 2025. In their analysis, much of the increased bioenergy demand is assumed to be 
91 satisfied through increased stump harvests, which are not widely used for commercial purposes

92 outside Scandinavia (Melin 2014).

93 In this study, we use the RCP-SSP scenario framework described in Fricko et al. (2016) to

94 translate global climate change mitigation scenarios into policy relevant forest scenarios for an

95 individual country. In Sweden, the forest sector provides 2.2\% of the GDP (SFA 2014). Timber

96 production is historically very important, and Sweden is one of the leading countries in the world

97 in the production of sawnwood (4\% of the global production), pulp for paper (6\%) as well as

98 paper and paperboard (3\%) even though the Swedish forest constitutes only $0.7 \%$ of the world's

99 forest area (FAOSTAT 2015). Forests cover 69\% of the Swedish land area, and are thus an

100 important feature in the Swedish landscape. Despite the relatively large forest area and a growing

101 standing stock, conflicts exist both on local and national level over use of the forest resource,

102 e.g., between production forestry, nature conservation, the usufruct rights of the indigenous Sami

103 people, hunting, tourism and recreation. With an increased future demand for forest products and

104 bioenergy, there will be a need for sound trade-offs among timber production and the

105 provisioning of other ecosystem services and biodiversity (see, e.g., Beland Lindahl et al. in

106 press; Sandström and Sténs 2015; Söderberg and Eckerberg 2013).

107 Few studies so far have explicitly covered the future of Swedish forests and forestry under

108 different scenarios of global development such as various climate change mitigation ambitions

109 and different paths of socioeconomic development. The national forest impact assessments have

110 focused only on the supply side and the harvesting potential (e.g., Claesson et al. 2015). To

111 complement the national forest impact assessment with analysis of potential demand, the

112 Swedish Forest Agency used scenarios with high global demand (increased consumption of

113 forest products in growing economies and increasing roundwood consumption due to mitigation 
114 efforts) and low global demand (forest products are substituted by other products and there is no

115 increase in roundwood consumption due to mitigation efforts) based on existing studies, which

116 indicates a positive development for the Swedish forest sector and a need for development of

117 value added products (Duvemo et al. 2015). The European Forest Sector Outlook Study II

118 (EFSOS II) included Sweden among other European countries and addressed the future

119 development of forests and the forest sector until 2030 on European level based on the global

120 development described in the IPCC scenario B2 (IPCC 2000) and four policy scenarios (UN

121 2011). The IPCC scenario B2 represents local solutions to sustainability problems in a world

122 with increasing human population, intermediate levels of economic development, and

123 technological change of moderate speed and diversity (IPCC 2000). The policy scenarios are

124 formulated to result from four different policy changes made based on the B2 assumptions:

125 Maximising biomass carbon, promoting wood energy, priority to biodiversity and fostering

126 innovation and competitiveness (UN 2011). The results show an increasing demand for forest

127 products and energy wood, and that the increasing pressure on forests potentially threatens

128 biodiversity. Moreover, the EUwood project (Mantau et al. 2010) compared three potential wood

129 supply scenarios (high, medium and low wood mobilization) for Europe with the future demand

130 for wood raw material from the industry and for energy based on the IPCC scenarios A1 and B2.

131 Results show that demand will exceed supply in 2030 under all scenarios. Based on the results

132 from the EUwood project, Jonsson (2013) focused on implications for the Swedish forest sector.

133 Results show that if the EU policy on renewable energy sources was fully implemented, there

134 would be an increasing demand on wood from Sweden for both material and energy uses. This

135 could favor the sawmill industry, while the demand for pulp and paper (above all newsprint) is

136 declining due to the developments in electronic information and communication technology. The 
137 pulp and paper industry may also have to compete with the bioenergy sector for raw material. In 138 a study on effects of global trends and market developments on the Swedish forest sector based 139 on qualitative scenarios and existing studies, Jonsson (2011) draws similar conclusions; under all 140 scenarios the Swedish solid wood-product industry would be well off, provided that the expected 141 growth in demand for factory-made, energy-efficient construction components takes place and

142 the industry adapts to this, but the future of the pulp and paper industry is more uncertain.

143 Recently, Bostedt et al. (2015) and FOREST EUROPE (2015) showed that the reported fellings

144 in Sweden are close to the potential, which would mean that substantial increase in demand may

145 be difficult to satisfy through increased harvests. To sum up, existing studies are focused on 146 wood production and show that the Swedish forest sector may have to prepare for restructuring

147 but that the future development seems to be positive overall. Consequences for biodiversity and 148 ecosystem services have not been explicitly included in these studies but some of them highlight 149 that there may be negative impacts from biomass production which have to be assessed in future 150 studies. This issue has also been pointed out by Verkerk et al. (2014) in a European level study 151 and by Berndes et al. (2003) in a review of global studies.

152 In this study, we use the land use model GLOBIOM-EU (Frank et al. 2016), a variant of the 153 Global Biosphere Management Model (Havlík et al. 2014; 2011), linked with Global Forest 154 Model (G4M), and the national forest modeling software Heureka RegWise (Wikström et al. 155 2011) to analyze the impacts of changes in the global wood demand on the Swedish forests. The 156 Swedish wood demand is projected until 2100 using GLOBIOM-EU, after which Heureka 157 RegWise is used to further analyze the implication of the projected harvest levels in terms of 158 regional forest development, and how such scenarios would affect the environmental values in 159 the Swedish forests. Through this linkage of two independent systems, we examine the effects of 
160 world-wide policies on a detailed national level, taking advantage of the individual strengths of

161 the two systems: the global competition between countries and land-use based activities as

162 presented in GLOBIOM-EU, and the detailed and nationally adjusted forest growth and yield

163 modeling of Heureka RegWise. With this approach, this study aims to broaden the perspective of

164 previous national level forest impact assessments to include a global outlook. More specifically,

165 the study aims to address the following questions:

- How will scenarios on global climate change mitigation policies reflect on the future harvest levels in Sweden?

- Is this demand possible to fulfill under the current forest regulations and policies in Sweden?

- How do the different climate change mitigation scenarios affect ecological aspects such as the amount of old forest and broadleaved forest?

\section{Material and methods}

173 In this chapter, we first introduce briefly the two models used in the study, the national forest

174 analysis tool Heureka RegWise and the global land use model GLOBIOM-EU. Then, we

175 describe the scenarios used in the analysis and explain how the national wood supply scenario

176 was combined with the global scenarios for wood demand.

\section{Heureka RegWise}

178 The Heureka system (Wikström et al. 2011) is an advanced forest decision support system for 179 analysis and planning of the forest landscape developed at the Swedish University of

180 Agricultural Sciences and is extensively used in Sweden by both researchers and forestry 181 professionals. Heureka provides various models and tools for forest planning on different levels 
182 that support the entire planning process. Heureka RegWise is the application for long-term

183 analysis on regional or national level and is based on a simulation approach. The core of Heureka

184 RegWise is the projection of the development of individual trees over time based on empirical

185 growth models, mainly derived from data from the Swedish National Forest Inventory (NFI).

186 The growth models are applicable to all Swedish tree species as well as mixed species stands and

187 are used to provide reliable growth predictions for up to 100 years (Fahlvik et al. 2014). To

188 project the development of individual trees, in addition to growth models there are models for

189 natural mortality (Fridman and Ståhl 2001) and in-growth (Wikberg 2004). The user can define

190 many settings for forest management activities such as final felling, regeneration, thinning,

191 fertilization, continuous cover forestry and nature conservation. Logistic regression functions are

192 used to calculate the probability of thinning and final felling based on information on what type

193 of stands thinning and final felling have been carried out on permanent NFI plots (Holm and

194 Lundström 2000).

195 Heureka RegWise can be used to develop scenarios for large geographical areas to answer 196 questions of "what if"-character. For example, the effects of various forest management

197 strategies, e.g., intensive forestry or continuous-cover forestry, on the output of timber

198 production and a number of other ecosystem services can be analyzed. Analyses with Heureka

199 RegWise are based primarily on data from the Swedish National Forest Inventory (NFI)

200 combined with data from digital maps.

\section{GLOBIOM-EU}

202 GLOBIOM-EU (Frank et al. 2016) is a version of the GLOBIOM partial-equilibrium model

203 (Havlík et al. 2014; 2011) with refined representation of EU28 Member States. Outside of EU, 
204 GLOBIOM and GLOBIOM-EU are identical in model structure and data sets as being used. The

205 most important features of the modeling approach are presented in Table 1.

206 INSERT TABLE 1 AROUND HERE

207 In its core, the GLOBIOM-EU is a global partial-equilibrium economic model representing land-

208 use based activities within the forest, agricultural, and bioenergy sectors. These sectors are

209 jointly considered within the model in a bottom-up approach based on detailed spatial

210 information on the biophysical conditions and technical costs associated with land use. A global

211 market equilibrium is determined through mathematical optimization where land use, utilization

212 of resources and processing activities are allocated to maximize the sum of producer and

213 consumer surplus subject to resource, technological, demand, trade, and policy constraints

214 (McCarl et al. 1980). Through the use of recursive dynamic optimization, the model is run with

21510 year time steps where production and international trade adjust to meet the demand for final

216 products at the level of 57 aggregated world regions (28 EU member countries, 29 regions

217 outside Europe). Each EU Member State, including Sweden, is thus covered based on the highest

218 available model resolution in terms of geographical and processing of commodities. Trade is also

219 modelled following the spatial equilibrium approach, meaning that trade flows are balanced out

220 between the geographical regions based on cost competitiveness and bilateral trade flows.

221 On the supply side, the GLOBIOM-EU model is based on a bottom-up approach with a detailed

222 disaggregated representation of land based activities. Outside of Europe, land based activities are

223 modeled at the level of simulation units (SimUs) - clusters of 5 arcminute pixels, with the same

224 characteristics in terms on slope, soil class, and altitude, and belonging to the same country and

$2250.5^{\circ} \times 0.5^{\circ}$ pixel. For EU, a more detailed SimU architecture is being used (except for Croatia, 
226 Cyprus, and Malta) and were the basic simulation unit is on the level of $1 \times 1 \mathrm{~km}$ pixel,

227 aggregated based on six altitude classes, seven slope classes, and soil (texture, depth, coarse

228 fragmentation), and belonging to the same NUTS2 region (Nomenclature of Territorial Units for

229 Statistics developed for the European Union).

230 For the representation of the forest GLOBIOM-EU receives data from the G4M model (Gusti

231 2010; Kindermann et al. 2008), which provides detailed geographic explicit information

232 concerning key forest management parameters (e.g., forest increment, harvesting costs, forest

233 carbon stocks, harvesting potentials by wood assortment). For the agricultural sector

234 representation, yields under different management systems are estimated by the biophysical crop

235 model called the Environmental Policy Integrated Climate model (EPIC) (Williams 1995) which

236 can then be used to calculate the impact of climate change on the agricultural sector (Havlík et al.

237 2015; Leclère et al. 2014).

\section{Scenarios}

\section{Harvest potential in Sweden: Supply potential scenario}

240 The present and future state of the Swedish forest have been regularly assessed in analyses of

241 harvesting potential since the 1980's and more recently in the more comprehensive forest impact

242 assessment (in Swedish: Skogliga konsekvensanalyser, SKA). The most recent forest impact

243 assessment, SKA15, was carried out using Heureka RegWise and the results were presented in

244 November 2015 (Claesson et al. 2015). In all, six scenarios covering the next 100 years until

2452110 were analyzed in SKA15. These scenarios were: Current forestry, Increased harvesting,

246 Decreased harvesting, Double set aside areas, Without climate effect, and With climate effect

247 RCP8.5. In the first four scenarios, a climate change effect corresponding to RCP4.5 is

248 modelled. This impact is manifested as an increase in growth rate of trees due to temperature 
249 rise, but does not include negative effects such as drought or pests. The process of development

250 and analysis of scenarios involved stakeholders from the forest sector, governmental agencies as

251 well as non-governmental organizations.

\section{INSERT FIGURE 1 AROUND HERE}

253 For this study, we analyze the future development of the Swedish forests based on the SKA15

254 Current forestry scenario, using the results for the whole of Sweden as well as for the four

255 regions Norra Norrland, Södra Norrland Svealand and Götaland (Figure 1). This scenario is

256 based on present forest management practice as observed in the NFI data and other sources such

257 as inventory data from the Forest Agency and information about conservation areas from digital

258 maps. The harvest level is the highest potential harvest level under the condition of sustainable

259 yield; that is, future harvest levels can increase over time but are not allowed to decrease. Thus,

260 in the following, this scenario is referred to as Supply potential. In this scenario the area of forest

261 set aside for nature conservation (including both formally and voluntarily protected areas) is the

262 same as today throughout the next 100 years, $16.3 \%$ of the forest area. These areas are simulated

263 to be left unmanaged for free development. The areas set aside are distributed over the four

264 regions and the types of areas set aside, are shown in Table 2. Reserves are formally protected

265 and their locations are known. The total set aside areas on voluntary basis is known, and

266 information on the location of the main part of these areas was acquired from the forest industry

267 and from forest owners' associations. Based on this information, additional areas with similar

268 qualities were selected and added to the category to make up for the total known area of

269 voluntary set aside areas. Small areas are also set aside in connection to final felling according to

270 the Swedish Forestry Act (e.g., wet areas, rocky outcrops and buffer zones). Information on such 
271 areas from the NFI, was used to select areas to be set aside in connection to final fellings in the 272 simulation.

273 INSERT TABLE 2 AROUND HERE

274

\section{Global scenario descriptions}

276 The demand analysis of this study is based on the new IPCC scenario framework, and

277 particularly assesses the impact of climate change mitigation across the RCP scenarios. The

278 RCPs were presented in the latest Assessment Report (AR5) of the Intergovernmental Panel for

279 Climate Change (IPCC 2014a; IPCC 2014b; IPCC 2013). The RCPs provide quantitative

280 information concerning the radiative forcing, ranging between 2.6 and $8.5 \mathrm{~W} / \mathrm{m}^{2}$ in the year 2100

281 (van Vuuren et al. 2011). Climate models estimate that these levels of radiative forcing lead to an

282 increase in the global temperature from below $1^{\circ} \mathrm{C}$ in RCP2.6 to about $7^{\circ} \mathrm{C}$ for RCP8.5 above

283 pre-industrial levels (Rogelj et al. 2012).

284 Alongside with the RCPs, a set of different scenarios for possible socio-economic development

285 has been developed (O'Neill et al. 2014). These Shared Socioeconomic Pathways (SSPs) depict

286 different development of the societies in terms of challenges for climate change mitigation and

287 adaptation. While the RCPs depict climate change development under different mitigation

288 policies, the SSPs focus on socio-economic development of the societies. A full scenario analysis

289 requires the use of a combination of both. For this study, we analyze the differences between the

290 RCP scenarios using the socio-economic development described by the SSP2, the "Middle of the

291 Way" pathway, with moderate challenges for climate change mitigation and adaptation (Fricko et

292 al. 2016). In this study, we use the population growth, economic development and land use 
293 patterns (most importantly, the development of short rotation plantation driven by carbon price

294 and bioenergy demand) for SSP2 as in Fricko et al. (2016). However, a full quantification of the 295 SSP scenarios is still underway, and especially drivers for the forestry sector have not yet been 296 fully developed. The development of other drivers is hence estimated by GLOBIOM-EU.

297 The RCP scenarios reflect both the expected outcome (change in climate) and the policies and 298 stabilization efforts taken to reach the outcome in terms of corresponding levels of radioactive 299 forcing. Most importantly for the modeling setup applied, the RCP scenarios differ in the amount 300 of bioenergy used to replace fossil fuels. In this study, we focus on three of the RCP scenarios: 301 RCP2.6, RCP4.5, and RCP8.5 (van Vuuren et al. 2011). This choice is taken so that the widest 302 range of future bioenergy demand can be assessed. Overall, the scenarios on the global level 303 show a clear change in the mix of energy carriers, with RCP8.5 having the lowest demand for 304 bioenergy and the RCP2.6 scenario having the strongest bioenergy demand. In these scenarios, 305 the projected total global energy demand from solid biomass increases from 32 EJ in 2000 to 60 306 EJ in RCP8.5 by 2100 (87\% increase to 2000), to 123 EJ in RCP4.5 (3-fold increase to 2000), 307 and and to 209 EJ in RCP2.6 (5.6-fold increase to 2000) (Fricko et al. 2016). The increasing 308 demand for bioenergy is used to substitute more carbon-intensive fossil fuels in the production of 309 electricity, heat, and biofuel production, and also to provide negative emissions through the use 310 of carbon capture and storage (CCS) technologies. The overall use of CCS is particularly

311 prominent and plays an important role in the RCP2.6 scenario for reaching the respective level of 312 radioactive forcing. In the current study, the total bioenergy demand is taken as an exogenous 313 input for each RCP, after which the GLOBIOM-EU model estimates the shares of the various 314 feedstocks as being used. To determine the demand for various energy feedstocks in this study 315 we rely on the output from the Model for Energy Supply Strategy Alternatives and their General 
316 Environmental Impact (MESSAGE) (McCollum et al. 2014). In this paper, the scenarios are

317 named Low demand (based on RCP8.5), Intermediate demand (RCP4.5) and High demand

318 (RCP2.6), referring to the total demand for wood biomass in the RCP scenarios.

\section{Combining Swedish and global scenarios}

320 The GLOBIOM-EU model framework was linked with the Heureka RegWise system for this

321 project as shown in Figure 2. The estimated initial forest area was calibrated in both systems to

322 the area of productive forest area as of the latest national forest inventory (Swedish NFI 2015).

323 This was necessary, because in the Swedish NFI, the productive forest area is defined as the area

324 of forest with a mean annual increment potential of at least $1 \mathrm{~m}^{3} \mathrm{a}^{-1}$, in contrast to the area used

325 by GLOBIOM-EU and its forest-development model G4M, which uses the land cover-based

326 estimates of FAO FRA (2010). Based on this calibrated forest area, GLOBIOM-EU was used to

327 estimate wood demand for Sweden under different biomass demand scenarios.

\section{INSERT FIGURE 2 AROUND HERE}

329 First, the global wood demand for Sweden was estimated by GLOBIOM-EU for Low,

330 Intermediate and High demand. The results are shown as harvest level estimates and compared

331 with the harvest level projections of the scenario Supply potential. An overview of the scenarios

332 is given in Table 3 and Table 4.

333 INSERT TABLE 3 AROUND HERE

334 INSERT TABLE 4 AROUND HERE

335 Second, the GLOBIOM-EU projected wood demands in Sweden were used as target harvest

336 levels in Heureka RegWise, all other assumptions for forest management being the same as in 
337 Supply potential. The results show the consequences of global wood demand for the Swedish

338 forests, and are analyzed in terms of effects on wood production variables and biodiversity

339 indicators.

340 The wood production variables reflect the main assortments in Swedish forestry: sawlogs and

341 pulpwood (see Table 5 for definitions). The volumes produced of these assortments are estimated

342 by Heureka RegWise based on tree diameter and the prevailing price list. Log quality is not

343 taken into account, which will lead to some overestimation of the amount of sawlogs over

344 pulpwood since in reality a certain share of sawlogs will be classed as pulpwood due to inferior

345 quality; however, the estimates based only on tree diameter are still valid as an indicator of the

346 general development of different types of assortments.

347 The environmental consequences are analyzed based on established set of indicators for

348 environmental quality. Sweden has set up 16 environmental quality objectives to assess the state

349 and development of the environment (Ministry of the Environment 2013). One of the objectives,

350 Sustainable Forests, focuses directly on the state of the forests, and two indicators for this

351 objective, the area of old forest and the area of old forest rich in broadleaves, are used in this

352 study to analyze the effects of global demand on biodiversity in the Swedish forests. The results

353 can be compared with observed development, as statistics of historical development are available

354 for these environmental indicators both on national and regional level.

355 The indicators relevant for this study are listed in Table 5. Harvest levels considered in this study

356 cover all harvests in productive forests (i.e., forests with an annual growth of $1 \mathrm{~m}^{3} \mathrm{ha}^{-1}$ or more).

357 These forests include also official or voluntary reserves, which are not primarily managed for

358 timber production, but where some harvests may still be done to promote ecological aspects, e.g., 
359 to preserve the age or tree species structure. For the assessment of the environmental indicators,

360 we show the development of the indicators both in all productive forests, including areas set

361 aside for nature conservation (“All productive forest”), and in areas which do not have any

362 restrictions for harvesting (“Managed productive forest”).

INSERT TABLE 5 AROUND HERE

\section{Results}

365 The Supply potential scenario shows an initial potential harvest level of 90.8 million $\mathrm{m}^{3}$ over 366 bark (o.b.) in 2010 and increases to ca 120 million $\mathrm{m}^{3}$ o.b. by year 2090 (Figure 3). In all three 367 demand scenarios the demand for wood is lower than the level of the Supply potential scenario

368 throughout the projection period. However, in the period from 2020 to 2040 all demand

369 scenarios display similar levels of high demand which are close to the potential supply, i.e., the

370 harvest level in the Supply potential scenario. From 2040, the demand scenarios show different

371 trajectories for the demand for wood; in High demand the demand is the highest and the level

372 rather close to the harvest level in Supply potential while the demand is lower in the Intermediate 373 demand and especially in the Low demand scenarios.

\section{INSERT FIGURE 3 AROUND HERE}

375 Using the harvest levels from the different demand scenarios as target harvest levels in Heureka

376 RegWise provides an output of sawlogs and pulpwood as shown in Figure 4. The output of

377 sawlogs is almost the same for all demand scenarios, and slightly lower than in the original

378 Supply potential scenario. In the scenarios with high wood demand, the final fellings are made

379 earlier, leading to an output of harvesting lower-diameter trees and more pulpwood compared to 380 scenarios with lower demand or the Supply potential scenario. The ratio of pulpwood to sawlogs 
381 is increasing somewhat over time in both the Supply potential scenario and in the demand 382 scenarios.

INSERT FIGURE 4 AROUND HERE

384 The effects on the environment from the demand for wood in the demand scenarios, as assessed 385 with the environmental quality objective indicators, are shown in Figures 5-7.

386 The area of old forest on all productive forest land (i.e., managed productive forest as well as 387 areas set aside for conservation) increases over time after an initial decrease but compared with 388 the original Supply potential scenario, the Low and Intermediate demand scenarios result in a 389 larger area of old forest over time, ca 370000 ha more in 2100, due to lower harvest levels 390 (Figure 5).

391 When only managed productive forests (i.e., the productive forest outside protected areas) is 392 considered, the area of old forest decreases initially with as much as 500000 to 600000 ha by 3932060 in both the Supply potential scenario and the demand scenarios (Figure 5). After 2060 the 394 area of old forest start to slightly increase again in the Low and Intermediate demand scenarios to 395 ca 700000 ha, and in the High demand scenario there is a slow increase up to 500000 ha. 396 However, in the Supply potential scenario the area of old forest stay on the level of around 397350000 ha.

\section{INSERT FIGURE 5 AROUND HERE}

399 As for the geographical distribution, the area of old forest is the same in northern Sweden ( $\mathrm{N}$ and 400 S Norrland) for the Intermediate demand and Supply potential scenarios; however, in Svealand 401 and especially Götaland the area of old forest is considerably larger in the Intermediate demand 
402 scenario (Figure 6). For clarity, the figures only show development in the Intermediate demand 403 and Supply potential scenarios; the Low demand scenario is almost identical to the Intermediate 404 demand scenario and High demand is closer to the Supply potential scenario.

406 The area of old forest rich in broadleaves increases initially in all scenarios, decreases after 2030 407 and then increases again around 2080. The pattern is similar in the Supply potential scenario and 408 the demand scenarios, with the largest changes in Supply potential and the smallest in

409 Intermediate and Low demand (Figure 7). Moreover, this pattern is visible when the total 410 productive forest area is considered as well as when only the managed productive forest area is 411 considered.

\section{INSERT FIGURE 7 AROUND HERE}

\section{Discussion}

414 Swedish forests are an important natural resource that is managed for providing a sustainable

415 yield of timber as well as for supplying a range of other ecosystem services and the preservation 416 of biodiversity. Many processes can be expected to affect the way the Swedish forests are 417 managed in the future. The Swedish forest impact assessments have addressed some different 418 national forest management scenarios but been focused mainly on the supply and harvesting 419 potential. In this study, we incorporate information on future global scenarios in the national420 scale forestry analysis to estimate wood demand, and hence offer a new viewpoint for the future 421 strategy development. The approach presented in this paper combines models and scenarios at 422 different levels, and could be used to analyze other countries or areas as well. 
423 The three demand scenarios analyzed in this study show essentially three levels of wood biomass

424 demand, high (RCP2.6), medium (RCP4.5) and low (RCP8.5). High global climate change

425 mitigation ambitions in the High demand scenario lead to a demand for biomass from Sweden

426 which is close to the harvesting potential, shown in Supply potential. However, in the next 25

427 years, the demand is so high in all demand scenarios that nearly the full harvesting potential in

428 Sweden has to be used in order to fulfill the demand, regardless of scenario. This finding is in

429 line with the results from the studies by Jonsson (2013; 2011) and Duvemo et al. (2015), and also

430 agrees with the analyses of the current harvest potential in FOREST EUROPE (2015) and

431 Bostedt et al. (2015). Thus, the harvest level will fulfill the condition of sustainable yield - albeit

432 barely - but the harvesting potential is exploited to the maximum extent. This result may either

433 not realize, or it may have severe consequences for the Swedish forests. First, it is not likely that

434 all the potential supply will be harvested in reality. The share of non-industrial private forest

435 owners is relatively large in Sweden: ca $50 \%$ of the productive forest, and $50 \%$ of privately

436 owned forest estates are 20 ha or smaller (SFA 2014). Consequently, many forest owners are not

437 directly dependent on the forest for income and prioritize other objectives than timber production

438 (Eggers et al. 2014). Because of this, it is likely that all harvest potential may not be easily

439 accessible in reality. Second, if the national Swedish forest policy would be directed towards

440 other goals such as increasing the area of productive forest to be set aside for nature

441 conservation, it may prove difficult to provide biomass on a level that would satisfy the global

442 demand. A scenario where the total area set aside is doubled was developed in the SKA15

443 project, resulting in a harvest level well below even the Low demand scenario until 2090

444 (Claesson et al. 2015). A doubled conservation area is not currently realistic in the Swedish

445 forest policy context but this scenario was set up to analyze the consequences of ambitious 
446 conservation objectives.It is assumed that policies that may be realized, even ambitious ones,

447 will fall somewhere in between this scenario and the Supply potential scenario. Third, woody

448 biomass is not the only component in the task to achieve the ambitious targets for climate

449 mitigation set in the High demand scenario. For instance, the scenario assumes that other types

450 of energy sources and carbon capture and storage (CCS) techniques are to be developed. If these

451 endeavors are not successful, the pressure on forests to produce renewable energy may be even

452 larger (Berndes et al. 2003).

453 Yet another uncertainty is the effect of climate change on Swedish forests. In the Heureka

454 RegWise simulations the climate effect is included as increasing forest growth rates; ca 21\%

455 higher by 2100 compared to simulations without climate effects (Claesson et al. 2015). The

456 Heureka RegWise estimate is based on the climate change effect in the RCP4.5 scenario and

457 would be lower if the RCP2.6 had been used. Thus, with the High demand scenario (RCP2.6) it

458 would have been likely to assume lower harvest potential than the present estimate in the Supply

459 potential scenario, further stressing the uncertainty to fulfill the condition of sustainable yield for

460 that combination of scenarios. The estimated increase in forest growth for the supply scenarios

461 could also be overestimated since the Heureka RegWise model did not include possible negative

462 effects by increased wind damage, droughts and pests related to climate change (Claesson et al.

463 2015).

464 All demand scenarios result in rather similar amounts of sawlogs over time, on levels that are

465 quite close also in the Supply potential scenario. The difference between the scenarios is in the

466 amount of pulpwood produced. This reflects the high demand for wood for energy purposes:

467 pulpwood quality roundwood is less valuable as feedstock for material purposes, and thus the

468 main source of roundwood for energy. Pulpwood is also mainly acquired from thinnings, while a 
469 major part of sawlogs are harvested in final fellings. On the high levels of wood demand

470 predicted in all demand scenarios, final harvests are likely to be made as early as possible, which

471 leads to a larger proportion of pulpwood from final fellings, as well as an overall trend of

472 decreasing age and dimensions of harvested forests. It should be noted that the current analysis

473 does not account for collection of harvest residues or stump harvests. Currently, the volume of

474 this residual biomass is only a fraction of the total harvests in Sweden, but could be increased

475 considerably if the technically feasible potentials (almost 20 mill. $\mathrm{m}^{3}$ altogether) were harvested

476 (Routa et al. 2013). Another possible bioenergy feedstock could be the small trees cut in

477 thinnings which are too small to be used as pulpwood and thus largely left in the forest. If these

478 additional energy feedstocks were harvested more actively, the pressure to increase pulpwood

479 harvests would likely be smaller than shown in our results. A number of studies have also shown

480 a large potential to increase forests production in the boreal landscape (e.g., Larsson et al. 2008;

481 Nilsson et al. 2011). Including new types of feedstocks as well as silvicultural measures to

482 further increase forest growth to the model framework would be an interesting topic for future

483 studies.

484 Sustainable yield means that harvest levels are sustainable in the long term, but this is not a

485 sufficient condition for sustainable forest management; ecological and social functions of the

486 forests should also be preserved and supported (Hahn and Knoke 2010). In this study, the area of

487 old forest and old forest rich in broadleaves are used as indicators for sustainable forest

488 management, and the results show that the area of old forest will continue to increase over time

489 in all demand scenarios in line with the recent historical trend. On a general national level this

490 indicates that the harvesting is sustainable even under the High demand scenario. However, most

491 of this increase takes place in areas set aside for conservation purposes. In managed productive 
492 forests outside conservation areas, much of the old forest is harvested in the near future to satisfy

493 the high demand and then slowly increases over time again when the demand as well as the area

494 of final felling decreases. In the case of the High demand scenario, with a continuous high

495 demand, the area of old forest levels off. Whether the forest management is sustainable or not

496 from an ecological point of view depends to a large extent on how the old forest is distributed

497 over the landscape and on which types of forests. Thus, since most of the old forest is found in

498 areas that are set aside, the distribution of these areas is important. However, only the locations

499 of formally protected areas are known. Locations and distribution in the landscape of voluntarily

500 set aside areas as well as areas set aside in connection to final felling, which make up 78\% of the

501 area set aside in productive forest, are likely to be more or less evenly distributed over estates

502 and in connection to final felling. This is however not known for certain and it is not possible to

503 evaluate the ecological functionality of the areas set aside without further studies on the spatial

504 distribution in the landscape and how this changes over time (see, e.g., Mönkkönen et al. 2014;

505 Shifley et al. 2006).

506 The results on regional level show that most of the remaining old forest in the managed

507 productive forest is harvested in northern Sweden ( $\mathrm{N}$ and $\mathrm{S}$ Norrland) in all scenarios due to the

508 high demand. To satisfy the demand, practically the full potential is harvested which also leads

509 to relatively early final fellings and no old forest left in the managed forest except for areas set

510 aside. In southern Sweden (Svealand and Götaland), the area of old forest is increasing more

511 over time in the scenarios Intermediate and Low demand compared with the Supply potential

512 scenario, meaning that the pressure for harvesting in these scenarios is lower than the potential

513 harvest level. 
514 In comparison to the area of old forest, the area of mature forest with a large share of

515 broadleaved trees is not constrained to the same extent by harvesting. This is an important

516 distinction between the two types of ecological indicators: broadleaved trees will be present also

517 in the managed productive forest since current forest management practices favors broadleaves

518 and the lowest allowable final felling age is high enough for development of this forest type to

519 take place.

520 The demand projections for woody biomass were calculated using a global model GLOBIOM-

521 EU, which is adapted to the EU but still provides a fairly coarse spatial definition of Sweden

522 compared to the national model Heureka RegWise. To capture the regional differences in the

523 results and allow for best possible estimates of the environmental impacts, we only used the

524 demand for the total harvest volume from GLOBIOM-EU, letting the timber assortments and

525 spatial distribution of the harvests be defined by Heureka RegWise. This approach allowed us to

526 include a global outlook dimension into a national forest analysis without an extensive

527 programming work that would be needed to fully integrate the models. However, as there is no

528 feedback loop from the national model back to the global model, we cannot analyze the effects

529 that the available timber assortments have on the forest product prices. While our estimates

530 provide good grounds for analyzing the ecosystems services impacts of the global scenarios,

531 further work would be needed to analyze the development of the forest-based industrial sector

532 development in Sweden.

533 In future studies, feedback from the national system (here, Heureka RegWise) should be

534 provided to the global model (here, GLOBIOM-EU), to analyze direct and indirect effects of the

535 national forest management strategies on trade and harvest levels in other countries (cf. Nepal et

536 al. 2016). Such an analysis could provide insight to what would be the consequences, e.g., on 
537 trade if wood supply from a specific country would decrease or increase. Additionally, it could

538 be used to investigate where the woody biomass would be produced if the supply from one

539 country would decrease and what the effects of this would be in both economic and ecological

540 terms. As discussed by Kallio et al. (2006), decreased supply of raw material through e.g.

541 increased protection may lead to increased imports and potentially a reduction or restructuring of

542 the forest sector, as well as indirect economic and ecological effects in the places where the

543 biomass is produced instead. Another pertinent topic for future studies is to include carbon

544 storage as an issue in the analysis to see how different demand scenarios and forest policies

545 affect the carbon storage both in the forest and in forest products (see, e.g., Lundmark et al. 546 2014).

\section{Conclusions}

548 In this study, we show that ambitious policies for global climate change mitigation are likely to 549 result in high harvest levels in Sweden With current forest management practices, the supply of

550 wood from Sweden is seen to be just sufficient to fulfill a high global demand; this would

551 however require mobilization of the full harvesting potential. Consequently, there are intricate

552 trade-offs to be dealt with concerning future forest management and land use. Our study shows

553 also that harvesting to fulfill a high demand could affect negatively the Swedish environmental

554 quality objective Sustainable forests, with especially preserving old forests becoming almost

555 fully reliant on protection areas.

556 The key strength of this analysis is that it combines the detailed knowledge and models on the

557 national level with an overview of the possible global developments in biomass demand. This

558 approach produced results that neither model alone could have provided, showcasing a global

559 outlook that is valuable for discussions on national forest strategies for the future. However, this 
560 study is focused on timber production and ecological aspects and based on biophysical and

561 economic modeling that could be developed further and refined. Moreover, it highlights the need

562 for further model development in order to explicitly include different ecosystem services and

563 social aspects in future studies. In a world where global agreements are increasingly affecting

564 individual countries, it is essential that the impacts of international policies are analyzed

565 thoroughly on the national level, using best possible knowledge on both the global development

566 as well as national circumstances. 


\section{Acknowledgements}

568 This study was financially supported by Future Forests. Future Forests is a multi-disciplinary

569 research programme supported by the Foundation for Strategic Environmental Research

570 (MISTRA), the Swedish Forestry Industry, the Swedish University of Agricultural Sciences

571 (SLU), Umeå University, and the Forestry Research Institute of Sweden (Skogforsk).The authors

572 thank the two anonymous reviewers for insightful comments that have greatly helped to improve

573 the paper. 


\section{References}

575 Beland Lindahl, K., Sténs, A., Sandström, C., Johansson, J., Lidskog, R., Ranius, T., and

576 Roberge, J.-M. In press. The Swedish forestry model: More of everything? For. Policy Econ., 577 corrected proof available online. doi: 10.1016/j.forpol.2015.10.012.

578 Berndes, G., Hoogwijk, M., and van den Broek, R. 2003. The contribution of biomass in the

579 future global energy supply: A review of 17 studies. Biomass Bioenergy 25(1): 1-28. doi:

580 10.1016/S0961-9534(02)00185-X

581 Bostedt, G., Mustonen, M., and Gong, P. 2015. Increasing forest biomass supply in Northern

582 Europe - Countrywide estimates and economic perspectives. Scand. J. For. Res. 31(3): 1-9. doi:

$583 \quad 10.1080 / 02827581.2015 .1089930$.

584 Claesson, S., Duvemo, K., Lundström, A., and Wikberg, P.-E. 2015. Skogliga

585 konsekvensanalyser 2015 - SKA 15. Rapport nr 10. Swedish Forest Agency, Jönköping,

586 Sweden. Available from http://shop.skogsstyrelsen.se/shop/9098/art17/31291417-4ef099-

587 Skogliga_konsekvensanalyser_webb.pdf [accessed 28 October 2015]. [In Swedish.]

588 Cramer, W., Kicklighter, D.W., Bondeau, A., Moore III, B., Churkina, G., Nemry, B., Ruimy, 589 A., and Schloss, A.L. 1999. Comparing global models of terrestrial net primary productivity 590 (NPP): overview and key results. GCB 5:1-15. doi: 10.1046/j.1365-2486.1999.00009.x.

591 Duvemo, K., Fridh, M., Joshi, S., Karlsson, S., and Svensson, S. A. 2015. Global framtida 592 efterfrågan på och möjligt utbud av virkesråvara. Rapport nr 4. Swedish Forest Agency, 593 Jönköping, Sweden. Available from http://shop.skogsstyrelsen.se/shop/9098/art8/26742708594 29c596-Global_webb.pdf [accessed 28 October 2015]. [In Swedish.] 
595 Eggers, J., Lämås, T., Lind, T., and Öhman, K. 2014. Factors influencing the choice of

596 management strategy among small-scale private forest owners in Sweden. For. 5(7): 1695-1716.

597 doi:10.3390/f5071695.

598 Fahlvik, N., Elfving, B., and Wikström, P. 2014. Evaluation of growth functions used in the

599 Swedish Forest Planning System Heureka. Silva Fenn. 48(2): article id 1013. doi:

$600 \quad 10.14214 /$ sf.1013.

601 FAO FRA. 2010. Global Forest Resources Assessment 2010. Available from

602 http://www.fao.org/forestry/fra/fra2010/en/ [accessed 28 October 2015].

603 FAOSTAT. 2015. Statistics of the Food and Agriculture Organization of the United Nations.

604 Available from http://faostat3.fao.org/home/E [accessed 28 October 2015].

605 Fontagné L., Gaulier G. \& Zignago S. 2008. Specialization across Varieties and North-South

606 Competition., Economic Policy, 2008, pp. 51-91

607 FOREST EUROPE. 2015. State of Europe’s Forests 2015. Ministerial Conference on the

608 Protection of Forests in Europe FOREST EUROPE Liaison Unit, Madrid. Available from

609 http://www.foresteurope.org/fullsoef2015 [accessed 14 March 2016].

610 Frank, S., Böttcher, H., Gusti, M., Havlík, P., Klaassen, G., Kindermann, G. and Obersteiner, M.

611 2016. Dynamics of the land use, land use change, and forestry sink in the European Union: the

612 impacts of energy and climate targets for 2030. Climatic Change. doi: 10.1007/s10584-016-

613 1729-7.

614 Fricko, O., Havlík, P., Rogelj, J., Klimont, Z., Gusti, M., Johnson, N., Kolp, P., Strubegger, M.,

615 Valin, H., Amann, M., Ermolieva, T., Forsell, N., Herrero, M., Heyes, C., Kindermann, G., Krey, 
616 V., McCollum, D., Obersteiner, M., Pachauri, S., Rao, S., Schmid, E., Schoepp, W. and Riahi, K.

617 The marker quantification of the Shared Socioeconomic Pathway 2: A middle-of-the-road

618 scenario for the $21^{\text {st }}$ century. Global Environmental Change. In press. doi:

619 10.1016/j.gloenvcha.2016.06.004.

620 Fridman, J. and Ståhl, G. 2001. A three-step approach for modelling tree mortality in Swedish 621 forests. Scand. J. For. Res. 16(5): 455-466. doi: 10.1080/02827580152632856.

622 Gallaun, H., Zanchi, G., Nabuurs, G.J., Hengeveld, G., Schardt, M., and Verkerk, P.J. 2010. EU623 wide maps of growing stock and above-ground biomass in forests based on remote sensing and 624 field measurements. For. Ecol. Manage. 260(3): 252-261. doi: 10.1016/j.foreco.2009.10.011.

625 GEA. 2012. Global Energy Assessment - Toward a Sustainable Future. Cambridge University 626 Press, Cambridge, UK and New York, NY, USA and the International Institute for Applied 627 Systems Analysis, Laxenburg, Austria.

628 Gusti, M. 2010. An algorithm for simulation of forest management decisions in the global forest 629 model. Artif. Intell. N4:45-49. Available from

630 http://dspace.nbuv.gov.ua/bitstream/handle/123456789/58342/05-Gusti.pdf [accessed 31 October $6312015]$.

632 Hahn, A., and Knoke, T. 2010. Sustainable development and sustainable forestry: analogies, 633 differences, and the role of flexibility. Eur. J. For. Res. 129(5): 787-801. doi: 10.1007/s10342634 010-0385-0.

635 Havlík, P., Leclère, D., Valin, H., Herrero, M., Schmid, E., Soussana, J.-F., Müller, C., and 636 Obersteiner, M. 2015. Global climate change, food supply and livestock production systems: A 
637 bioeconomic analysis. In Climate change and food systems: global assessments and implications

638 for food security and trade. Edited by A. Elbehri. Food Agriculture Organization of the United

639 Nations (FAO), Rome, Italy. pp.178-197. Available from http://www.fao.org/3/a-

640 i4332e/i4332e06.pdf [accessed 31 October 2015].

641 Havlík, P., Schneider, U.A., Schmid, E., Böttcher, H., Fritz, S., Skalský, R., Aoki, K., De Cara,

642 S., Kindermann, G., Kraxner, F., Leduc, S., McCallum, I., Mosnier, A., Sauer, T., and

643 Obersteiner, M. 2011. Global land-use implications of first and second generation biofuel targets.

644 Energy Policy 39(10): 5690-5702. doi.org/10.1016/j.enpol.2010.03.030.

645 Havlík, P., Valin, H., Herrero, M., Obersteiner, M., Schmid, E., Rufino, M.C., Mosnier, A.,

646 Thornton, P.K., Böttcher, H., Conant, R.T., Frank, S., Fritz, S., Fuss, S., Kraxner, F., and

647 Notenbaert, A. 2014. Climate change mitigation through livestock system transitions. PNAS

648 111(10): 3709-3714. doi: 10.1073/pnas.1308044111.

649 Herrero, M., Havlík, P., McIntire, J., Palazzo, A., and Valin, H. 2014. African Livestock Futures:

650 Realizing the potential of livestock for food security, poverty reduction and the environment in

651 Sub-Saharan Africa. Office of the Special Representative of the UN Secretary General for Food

652 Security and Nutrition and the United Nations System Influenza Coordination.

653 Herrero, M., Havlík, P., Valin, H., Notenbaert, A., Rufino, M. C., Thornton, P. K., Blümmel,

654 M.B., Weiss, F.C., Grace, D.B., and Obersteiner, M. 2013. Biomass use, production, feed

655 efficiencies, and greenhouse gas emissions from global livestock systems. PNAS 110(52):

656 20888-20893. doi: 10.1073/pnas.1308149110. 
657 Holm, S. and Lundström, A. 2000. Åtgärdsprioriteter. Arbetsrapport no. 73. Department of

658 Forest Resource Management, Swedish University of Agricultural Sciences, Umeå. [In

659 Swedish.] Available from http://pub.epsilon.slu.se/8793/ [accessed 9 March 2016].

660 IEA. 2015. Energy Technology Perspectives 2015 - Mobilizing Innovation to Accelerate

661 Climate Action. IEA Publications, Paris, France. 418 pp.

662 IPCC. 2000. Emission scenarios. Cambridge University Press, Cambridge, United Kingdom and 663 New York, NY, USA.

664 IPCC. 2013. Climate Change 2013: The Physical Science Basis. Contribution of Working Group

665 I to the Fifth Assessment Report of the Intergovernmental Panel on Climate Change. Cambridge 666 University Press, Cambridge, United Kingdom and New York, NY, USA.

667 IPCC. 2014a. Climate Change 2014: Impacts, Adaptation, and Vulnerability. Part A: Global and 668 Sectoral Aspects. Contribution of Working Group II to the Fifth Assessment Report of the 669 Intergovernmental Panel on Climate Change. Cambridge University Press, Cambridge, United 670 Kingdom and New York, NY, USA.

671 IPCC. 2014b. Climate Change 2014: Mitigation of Climate Change. Contribution of Working

672 Group III to the Fifth Assessment Report of the Intergovernmental Panel on Climate Change.

673 Cambridge University Press, Cambridge, United Kingdom and New York, NY, USA.

674 Jansson, T., Heckelei, T., 2009. A new estimator for trade costs and its small sample properties.

675 Economic Modelling 26 (2), 489-498.

676 Jonsson, R. 2011. Trends and possible future developments in global forest-product markets677 implications for the Swedish forest sector. For. 2(1): 147-167. doi:10.3390/f2010147. 
678 Jonsson, R. 2013. How to cope with changing demand conditions - the Swedish forest sector as a

679 case study: An analysis of major drivers of change in the use of wood resources. Can. J. For.

680 Res. 43(4): 405-418. doi: 10.1139/cjfr-2012-0139.

681 Kallio, A. M. I., Moiseyev, A., and Solberg, B. 2006. Economic impacts of increased forest

682 conservation in europe: A forest sector model analysis. Environmental Science \& Policy 9(5):

683 457-465. doi: 10.1016/j.envsci.2006.03.002

684 Kallio, A. M. I., Salminen, O., and Sievänen, R. 2016. Forests in the Finnish low carbon

685 scenarios. J. For. Econ. 23: 45-61. doi: 10.1016/j.jfe.2015.12.001.

686 Kindermann, G.E., Obersteiner, M., Rametsteiner, E., and McCallum, I. 2006. Predicting the 687 deforestation-trend under different carbon-prices. Carbon Balance Manage. 1:15. doi:

688 10.1186/1750-0680-1-15.

689 Kindermann, G.E., McCallum, I., Fritz, S., and Obersteiner M. 2008. A global forest growing 690 stock, biomass and carbon map based on FAO statistics. Silva Fenn. 42(3): 387-396. Available 691 from http://m.metla.eu/silvafennica/full/sf42/sf423387.pdf [accessed 14 March 2016].

692 Kindermann, G., Obersteiner, M., Sohngen, B., Sathaye, J., Andrasko, K., Rametsteiner, E., 693 Schlamadinger, B., Wunder, S. and Beach, R.H. 2008. Global cost estimates of reducing carbon 694 emissions through avoided deforestation. PNAS 105(30): 10302-10307. doi:

695 10.1073/pnas.0710616105.

696 Larsson, S., Lundmark, T., and Ståhl, G. 2008. Möjligheter till intensivodling av skog. 697 Slutrapport från regeringsuppdrag Jo 2008/1885. Swedish University of Agricultural Sciences, 698 Uppsala, Sweden. Available from http://www.slu.se/Documents/externwebben/overgripande-slu- 
699 dokument/miljoanalys-dok/rapporter/Mint09/MINTSlutrapport.pdf [accessed 31 October 2015].

700 [In Swedish with English summary.]

701 Latta, G. S., Sjølie, H. K., and Solberg, B. 2013. A review of recent developments and

702 applications of partial equilibrium models of the forest sector. J. For. Econ. 19(4): 350-360. doi:

$703 \quad$ 10.1016/j.jfe.2013.06.006.

704 Leclère, D., Havlík, P., Fuss, S., Schmid, E., Mosnier, A., Walsh, B., Valin, H., Herrero, M.,

705 Khabarov, N., and Obersteiner, M. 2014. Climate change induced transformations of agricultural

706 systems: insights from a global model. Environ. Res. Lett. 9(12): 124018. doi: 10.1088/1748-

$7079326 / 9 / 12 / 124018$.

708 Lundmark, T., Bergh, J., Hofer, P., Lundström, A., Nordin, A., Poudel, B.C., Sathre, R.,

709 Taverna, R., and Werner, F. 2014. Potential roles of Swedish forestry in the context of climate

710 change mitigation. For. 5(4): 557-578. doi:10.3390/f5040557.

711 Mantau, U., Saal, U., Steierer, F., Verkerk, H., Lindner, M., Anttila, P., Asikainen, A.,

712 Oldenburger, J., Leek, N., and Prins, K. 2010. EUwood - Real potential for changes in growth

713 and use of EU forests. Final report. EUwood, Hamburg, Germany. Available from

714 http://www.egger.com/downloads/bildarchiv/187000/1_187099_DV_Real-potential-changes-

715 growth_EN.pdf [accessed 31 October 2015].

716 McCarl, B.A., and Spreen, T.H. 1980. Price endogenous mathematical programming as a tool for

717 sector analysis. Am. J. Agric. Econ. 62(1): 87-102. 
718 McCollum, D., Krey, V., Kolp, P., Nagai, Y., Riahi, K. 2014. Transport electrification: A key

719 element for energy system transformation and climate stabilization. Clim. Change 123(3): 651720 664. doi:10.1007/s10584-013-0969-z.

721 Melin, Y. 2014. Impacts of stumps and roots on carbon storage and bioenergy use in a climate

722 change context. Acta Universitatis agriculturae Sueciae 79. Doctoral thesis. Swedish University

723 of Agricultural Sciences, Umeå. Available from http://pub.epsilon.slu.se/11532/ [accessed 9

724 March 2016].

725 Ministry of the Environment. 2013. The Swedish environmental objectives system. Information

726 sheet from the Ministry of the Environment, Article no. M2013.01. Available at

727 http://www.miljomal.se/Global/24_las_mer/broschyrer/the-swedish-environmental-objectives-

728 system-M201301.pdf [accessed 29 October 2015].

729 Mönkkönen, M., Juutinen, A., Mazziotta, A., Miettinen, K., Podkopaev, D., Reunanen, P.,

730 Salminen, H., and Tikkanen, O.-P. 2014. Spatially dynamic forest management to sustain

731 biodiversity and economic returns. J. Environ. Manage. 134: 80-89. doi:

$732 \quad$ 10.1016/j.jenvman.2013.12.021.

733 Nepal P., Ince, P., Skog, K, and Chang, S. 2012. Projection of US forest sector carbon

734 sequestration under US and global timber market and wood energy consumption scenarios,

735 2010-2060. Biomass Bioenergy 45: 251-264. doi:10.1016/j.biombioe.2012.06.011.

736 Nilsson, U., Fahlvik, N., Johansson, U., Lundström, A., and Rosvall, O. 2011. Simulation of the

737 effect of intensive forest management on forest production in Sweden. For. 2(1): 373-393.

738 doi:10.3390/f2010373. 
739 O’Neill, B., Kriegler, E., Riahi, K., Ebi, K., Hallegatte, S., Carter, T., Mathur, R., and Vuuren, D.

740 2014. A new scenario framework for climate change research: the concept of shared

741 socioeconomic pathways. Clim. Change 122(3): 387-400. doi: 10.1007/s10584-013-0905-2.

742 Raunikar, R., Buongiorno, J., Turner, J. A., and Zhu, S. 2010. Global outlook for wood and

743 forests with the bioenergy demand implied by scenarios of the Intergovernmental Panel on

744 Climate Change. For. Policy Econ. 12(1): 48-56. doi: 10.1016/j.forpol.2009.09.013.

745 Rogelj, J., Meinshausen, M., and Knutti, R. 2012. Global warming under old and new scenarios

746 using IPCC climate sensitivity range estimates. Nat. Clim. Change 2: 248-253.

747 doi:10.1038/nclimate1385.

748 Routa, J., Asikainen, A., Björheden, R., Laitila, J., and Röser, D. 2013. Forest energy

749 procurement: state of the art in Finland and Sweden. Wiley Interdiscip. Rev.: Energy Environ.

750 2(6): 602-613. doi: 10.1002/wene.24.

751 Sandström C. and Sténs A. 2015. Dilemmas in Forest Policy Development: The Swedish

752 Forestry Model under Pressure. In The Future Use of Nordic Forests: A Global Perspective.

753 Edited by E. Westholm, K. Beland Lindahl and F. Kraxner. Springer, Cham, pp. 145-158.

754 SFA. 2014. Swedish Statistical Yearbook of Forestry 2014. Swedish Forest Agency, Jönköping,

755 Sweden. Available from http://www.skogsstyrelsen.se/en/AUTHORITY/Statistics/Statistical-

756 Yearbook-/ [accessed 28 October 2015].

757 Shifley, S.R., Thompson Iii, F.R., Dijak, W.D., Larson, M.A., and Millspaugh, J.J. 2006.

758 Simulated effects of forest management alternatives on landscape structure and habitat suitability 
759 in the Midwestern United States. For. Ecol. Manage. 229(1-3): 361-377. doi:

760 doi:10.1016/j.foreco.2006.04.030.

761 Söderberg, C. and Eckerberg, K. 2013. Rising policy conflicts in Europe over bioenergy and

762 forestry. For. Policy Econ. 33: 112-119. doi: 10.1016/j.forpol.2012.09.015.

763 Swedish NFI. 2015. Forest Statistics. Swedish National Forest Inventory. Available from

764 http://www.slu.se/foreststatistics [accessed 9 September 2015].

765 Toppinen, A. and Kuuluvainen, J. 2010. Forest sector modelling in Europe - the state of the art

766 and future research directions. For. Pol. Econ. 12(1): 2-8. doi: 10.1016/j.forpol.2009.09.017.

767 UN. 2011. European Forest Sector Outlook Study II 2010-2030. United Nations, UNECE/FAO

768 Timber Branch, Geneva, Switzerland. Available from

769 https://www.unece.org/fileadmin/DAM/timber/publications/sp-28.pdf [accessed 28 October

770 2015].

771 van Vuuren, D.P., Edmonds, J., Kainuma, M., Riahi, K., Thomson, A., Hibbard, K., Hurtt, G.C.,

772 Kram, T., Krey, V., Lamarque, J.-F., Masui, T., Meinshausen, M., Nakicenovic, N., Smith, S.,

773 and Rose, S.K. 2011. The representative concentration pathways: an overview. Clim. Change

774 109(1): 5-31. doi: 10.1007/s10584-011-0148-z.

775 van Vuuren, D., Kriegler, E., O’Neill, B., Ebi, K., Riahi, K., Carter, T., Edmonds, J., Hallegatte,

776 S., Kram, T., Mathur, R., and Winkler, H. 2014. A new scenario framework for Climate Change

777 Research: scenario matrix architecture. Clim. Change 122(3): 373-386. doi: 10.1007/s10584-

778 013-0906-1. 
779 Verkerk, P.J., Mavsar, R., Giergiczny, M., Lindner, M., Edwards, D., and Schelhaas, M.J. 2014.

780 Assessing impacts of intensified biomass production and biodiversity protection on ecosystem

781 services provided by European forests. Ecosyst. Serv. 9: 155-165. doi:

$782 \quad 10.1016 /$ j.ecoser.2014.06.004

783 Wikberg, P.-E. 2004. Occurrence, morphology and growth of understory saplings in Swedish

784 forests. Acta Universitatis agriculturae Sueciae, Silvestria 322. Doctoral thesis. Swedish

785 University of Agricultural Sciences, Umeå. Available from http://pub.epsilon.slu.se/610/

$786 \quad$ [accessed 9 March 2016].

787 Wikström, P., Edenius, L., Elfving, B., Eriksson, L.O., Lämås, T., Sonesson, J., Öhman, K.,

788 Wallerman, J., Waller, C., and Klintebäck, F. 2011. The Heureka forestry decision support

789 system: An overview. MCFNS 3(2): 87-95. Available from http://mcfns.com [accessed 28

790 October 2015].

791 Williams, J.R. 1995. The EPIC model. In Water Resources Publications. Edited by V.P. Singh.

792 Water Resources Publications, Highlands Ranch, Colorado. pp. 909-1000. 


\section{Tables}

794 Table 1. The data sources used in the GLOBIOM model framework.

\begin{tabular}{|c|c|c|}
\hline & Europe & Globally \\
\hline Land cover & Corine land cover maps & GLC2000 (Global Land Cover) \\
\hline \multicolumn{3}{|l|}{ Forest } \\
\hline $\begin{array}{l}\text { Initial forest growing } \\
\text { stock }\end{array}$ & Gallaun et al. (2010) & Kindermann et al. (2008) \\
\hline Forest NPP & Cramer et al. (1999) & Cramer et al. (1999) \\
\hline Biomass map & Kindermann et al. (2008) & Kindermann et al. (2008) \\
\hline Forest species & $\begin{array}{l}\text { Fir, spruce, pine, birch, beech, } \\
\text { oak and larch }\end{array}$ & $\begin{array}{l}\text { Evergreen, deciduous, needle- } \\
\text { leaved, broadleaved }\end{array}$ \\
\hline $\begin{array}{l}\text { Wood harvesting } \\
\text { commodities }\end{array}$ & $\begin{array}{l}\text { pulpwood, sawlogs, traditional } \\
\text { firewood/fuelwood, harvesting } \\
\text { residues, other wood products) }\end{array}$ & $\begin{array}{l}\text { pulpwood, sawlogs, traditional } \\
\text { firewood/fuelwood, harvesting } \\
\text { residues, other wood products) }\end{array}$ \\
\hline Wood processing residues & $\begin{array}{l}\text { bark, black liquor, sawdust, and } \\
\text { sawchips }\end{array}$ & $\begin{array}{l}\text { bark, black liquor, sawdust, and } \\
\text { sawchips }\end{array}$ \\
\hline $\begin{array}{l}\text { Semi-finished woody } \\
\text { products }\end{array}$ & $\begin{array}{l}\text { sawnwood, mechanical pulp, } \\
\text { chemical pulp, plywood, } \\
\text { particleboard }\end{array}$ & $\begin{array}{l}\text { sawnwood, mechanical pulp, } \\
\text { chemical pulp, plywood, } \\
\text { particleboard }\end{array}$ \\
\hline $\begin{array}{l}\text { Production of } \\
\text { commodities as of } 2010\end{array}$ & FAOSTAT statistics & FAOSTAT statistics \\
\hline Harvesting costs & Kindermann et al. (2006) & Kindermann et al. (2006) \\
\hline \multicolumn{3}{|l|}{ Agriculture } \\
\hline Management systems & $\begin{array}{l}3 \text { alternative tillage systems and } \\
2 \text { alternative irrigation and } \\
\text { fertilization systems }\end{array}$ & 4 different management systems \\
\hline Coverage of crops & $\begin{array}{l}\text { barley, corn, corn silage, cotton, } \\
\text { fallow, flax, oats, other green } \\
\text { fodder, peas, potato, rapeseed, } \\
\text { rice, rye, soybeans, sugar beet, } \\
\text { sunflower, soft- and durum } \\
\text { wheat }\end{array}$ & $\begin{array}{l}\text { barley, dry beans, cassava, peas, } \\
\text { corn, cotton, groundnuts, millet, } \\
\text { potato, rapeseed, rice, soybeans, } \\
\text { sorghum, sugar cane, sunflower, } \\
\text { sweet potatoes, wheat, palm oil }\end{array}$ \\
\hline $\begin{array}{l}\text { Production of } \\
\text { commodities as of } 2010\end{array}$ & EUROSTAT statistics & FAOSTAT statistics \\
\hline \multicolumn{3}{|l|}{ Livestock } \\
\hline Production systems & $\begin{array}{l}8 \text { aggregate systems for } \\
\text { ruminants }\end{array}$ & 8 aggregate systems for ruminants \\
\hline Species aggregates & $\begin{array}{l}\text { cattle and buffaloes (bovines), } \\
\text { sheep and goats (small } \\
\text { ruminants), pigs, and poultry }\end{array}$ & $\begin{array}{l}\text { cattle and buffaloes (bovines), } \\
\text { sheep and goats (small ruminants), } \\
\text { pigs, and poultry }\end{array}$ \\
\hline Total animal products & $\begin{array}{l}\text { beef, lamb, pig, and poultry } \\
\text { meat, bovine and small } \\
\text { ruminant milk and eggs }\end{array}$ & $\begin{array}{l}\text { beef, lamb, pig, and poultry meat, } \\
\text { bovine and small ruminant milk } \\
\text { and eggs }\end{array}$ \\
\hline Parametrization of & Herrero et al. 2013 & Herrero et al. 2013 \\
\hline
\end{tabular}




\begin{tabular}{|c|c|c|}
\hline \multicolumn{3}{|l|}{ production systems } \\
\hline Trade & & \\
\hline Historical trade flows & Gaulier et al. 2008 & Gaulier et al. 2008 \\
\hline $\begin{array}{l}\text { Trade calibration } \\
\text { approach }\end{array}$ & Jansson et al. 2009 & Jansson et al. 2009 \\
\hline Traded forest products & $\begin{array}{l}\text { pulpwood, saw logs, sawnwood, } \\
\text { mechanical pulp, chemical pulp, } \\
\text { plywood, particleboard }\end{array}$ & $\begin{array}{l}\text { pulpwood, saw logs, sawnwood, } \\
\text { mechanical pulp, chemical pulp, } \\
\text { plywood, particleboard }\end{array}$ \\
\hline $\begin{array}{l}\text { Traded agriculture } \\
\text { products }\end{array}$ & $\begin{array}{l}\text { barley, corn, corn silage, cotton, } \\
\text { fallow, flax, oats, other green } \\
\text { fodder, peas, potato, rapeseed, } \\
\text { rice, rye, soybeans, sugar beet, } \\
\text { sunflower, soft- and durum } \\
\text { wheat }\end{array}$ & $\begin{array}{l}\text { barley, dry beans, cassava, peas, } \\
\text { corn, cotton, groundnuts, millet, } \\
\text { potato, rapeseed, rice, soybeans, } \\
\text { sorghum, sugar cane, sunflower, } \\
\text { sweet potatoes, wheat, palm oil }\end{array}$ \\
\hline Traded livestock products & $\begin{array}{l}\text { beef, lamb, pig, and poultry } \\
\text { meat, bovine and small } \\
\text { ruminant milk and eggs }\end{array}$ & $\begin{array}{l}\text { beef, lamb, pig, and poultry meat, } \\
\text { bovine and small ruminant milk } \\
\text { and eggs }\end{array}$ \\
\hline
\end{tabular}


797 Table 2. Type and areas of set asides distributed over four regions in Sweden

\begin{tabular}{lllll}
\hline & $\begin{array}{l}\text { Total area of } \\
\text { productive } \\
\text { forest }\end{array}$ & Formal reserves & $\begin{array}{l}\text { Areas set aside } \\
\text { on voluntary } \\
\text { basis }\end{array}$ & $\begin{array}{l}\text { Areas set aside in } \\
\text { connection to } \\
\text { final fellings }\end{array}$ \\
\hline N Norrland & 6953 & $486(7 \%)$ & $543(7.8 \%)$ & $449(6.5 \%)$ \\
S Norrland & 5768 & $105(1.8 \%)$ & $319(5.5 . \%)$ & $538(9.3 \%)$ \\
$\begin{array}{l}\text { Svealand } \\
\text { Götaland }\end{array}$ & 5364 & $131(2.4 \%)$ & $276(5.1 \%)$ & $329(6.1 \%)$ \\
$\begin{array}{l}\text { Total for } \\
\text { Sweden }\end{array}$ & 5014 & $100(2.0 \%)$ & $197(3.9 \%)$ & $302(6.0 \%)$ \\
\hline
\end{tabular}

798

799 
Table 3. Scenarios used in the study

\begin{tabular}{lll}
\hline & Scenario & Basis for the scenario \\
\hline $\begin{array}{l}\text { Supply scenario } \\
\text { as in } \\
\text { Claesson et al. (2015) }\end{array}$ & $\begin{array}{l}\text { Supply potential } \\
\begin{array}{l}\text { Demand scenarios } \\
\text { based on }\end{array}\end{array}$ & $\begin{array}{l}\text { SKA15 Current forestry. Forest harvests in Sweden } \\
\text { are the highest possible under sustainable yield over } \\
\text { time. }\end{array}$ \\
$\begin{array}{ll}\text { Fricko et al. 2016 } \\
\text { Intermediate demand }\end{array}$ & $\begin{array}{l}\text { RCP8.5: low policy efforts to mitigate climate change, } \\
\text { low bioenergy demand. }\end{array}$ \\
& High demand & $\begin{array}{l}\text { RCP4.5: intermediate policy efforts to mitigate } \\
\text { climate change, intermediate bioenergy demand } \\
\text { RCP2.6: ambitious policy efforts to mitigate climate } \\
\text { change, high bioenergy demand }\end{array}$ \\
\hline
\end{tabular}

801

802 Table 4. Outcome of the scenarios for Sweden in terms of demand of woody biomass feedstock

803 for bioenergy production (including solid and liquid woody biomass feedstocks for energy

804 production), production of semi-finished woody products commodities, and net trade of woody

805 products (wood harvesting commodities and semi-finished woody products). The scenarios are

806 here presented as the relative change to 2010.

\begin{tabular}{clllllllllll}
\hline Variable/Indicator & Scenario & $\mathbf{2 0 1 0}$ & $\mathbf{2 0 2 0}$ & $\mathbf{2 0 3 0}$ & $\mathbf{2 0 4 0}$ & $\mathbf{2 0 5 0}$ & $\mathbf{2 0 6 0}$ & $\mathbf{2 0 7 0}$ & $\mathbf{2 0 8 0}$ & $\mathbf{2 0 9 0}$ & $\mathbf{2 1 0 0}$ \\
\hline \multirow{2}{*}{$\begin{array}{c}\text { Bioenergy } \\
\text { demand }\end{array}$} & $\mathbf{R C P 2 . 6}$ & 1.00 & 1.23 & 1.47 & 1.61 & 1.63 & 1.59 & 1.86 & 2.00 & 2.05 & 2.07 \\
& $\mathbf{R C P 4 . 5}$ & 1.00 & 1.25 & 1.44 & 1.57 & 1.62 & 1.59 & 1.57 & 1.58 & 1.54 & 1.53 \\
& $\mathbf{R C P 8 . 5}$ & 1.00 & 1.25 & 1.43 & 1.57 & 1.60 & 1.56 & 1.53 & 1.56 & 1.52 & 1.52 \\
\hline \multirow{2}{*}{$\begin{array}{c}\text { Production of } \\
\text { semi-finished }\end{array}$} & $\mathbf{R C P 2 . 6}$ & 1.00 & 1.08 & 1.16 & 1.22 & 1.27 & 1.27 & 1.34 & 1.41 & 1.47 & 1.48 \\
woody products & $\mathbf{R C P} \mathbf{5}$ & 1.00 & 1.09 & 1.16 & 1.21 & 1.26 & 1.27 & 1.28 & 1.29 & 1.32 & 1.34 \\
& $\mathrm{RCP}$ & 1.00 & 1.09 & 1.17 & 1.22 & 1.26 & 1.27 & 1.27 & 1.28 & 1.29 & 1.30 \\
\hline \multirow{2}{*}{$\begin{array}{c}\text { Net trade of } \\
\text { woody products }\end{array}$} & $\mathbf{R C P 2 . 6}$ & 1.00 & 1.32 & 1.68 & 1.85 & 1.91 & 1.91 & 1.79 & 1.90 & 1.87 & 1.86 \\
& $\mathbf{R C P 4 . 5}$ & 1.00 & 1.33 & 1.70 & 1.74 & 1.86 & 1.88 & 1.91 & 1.91 & 1.93 & 1.93 \\
& $\mathrm{RCP8.5}$ & 1.00 & 1.33 & 1.69 & 1.83 & 1.90 & 2.02 & 2.04 & 2.05 & 2.05 & 2.06 \\
\hline
\end{tabular}

807

808 
809 Table 5. List of the wood production variables and environmental indicators used in this study.

\begin{tabular}{ll}
\hline Variable/Indicator & Definition \\
\hline Sawlogs & Length of logs $>=310 \mathrm{~cm}$ and $<=550 \mathrm{~cm}$. Diameter at the top $>=12 \mathrm{~cm}$. \\
Pulpwood & Length of logs $>=300 \mathrm{~cm}$ and $<=500 \mathrm{~cm}$. Diameter at the top $>=5 \mathrm{~cm}$. \\
Area of old forest & $\begin{array}{l}\text { Forest age }>140 \text { years in northern Sweden (Norrland, Dalarna, } \\
\text { Värmland och Örebro counties), and }>120 \text { years in the rest of the } \\
\text { country }\end{array}$ \\
Area of old forest, rich in & $\begin{array}{l}\text { Forest in which }>=25 \% \text { of the basal area consists of broadleaved trees } \\
\text { and the forest age is }>80 \text { years in northern Sweden (Norrland, Dalarna, } \\
\text { broadleaved trees }\end{array}$ \\
$\begin{array}{l}\text { Värmland and Örebro counties), and }>60 \text { years in the rest of the } \\
\text { country. }\end{array}$
\end{tabular}




\section{Figure captions}

812 Figure 1. Map of Sweden with the four regions delineated.

813 Figure 2. Schematic description of the model interlinkage.

814 Figure 3. Total harvest of wood projected for Sweden for 2010-2100 in the supply scenario

815 (Supply potential) and in the demand scenarios (High, Intermediate and Low demand), as well as

816 the historical harvest development for 1956-2009 (SFA 2014).

817 Figure 4. Volume of pulpwood and sawlogs harvested in the different scenarios.

818 Figure 5. The development of old forest area in the supply and demand scenarios on all

819 productive forest land and on the share of productive forest land managed for biomass

820 production and the historical development on all productive forest land (Swedish NFI 2015).

821 Figure 6. The development of old forest area on all productive forest land in the four regions of

822 Sweden in the Supply potential and the Intermediate demand scenarios, and the historical

823 development on all productive forest land in the regions (Swedish NFI 2015).

824 Figure 7. Development of the area of old forest rich in broadleaves in the different supply and

825 demand scenarios and the historical development for managed productive forest (Swedish NFI 826 2015). 


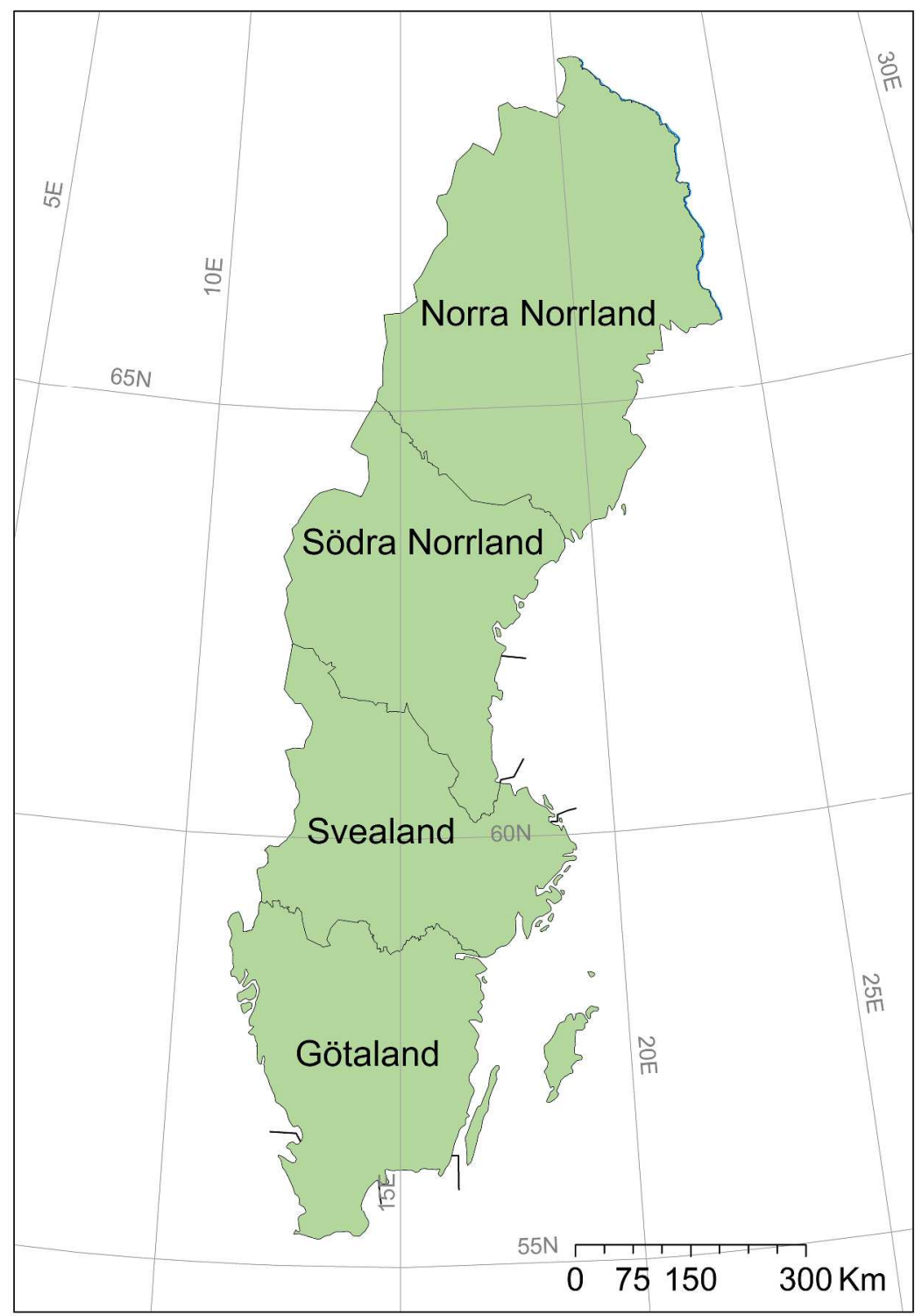

Figure 1. Map of Sweden with the four regions delineated. $297 \times 420 \mathrm{~mm}(300 \times 300$ DPI $)$ 


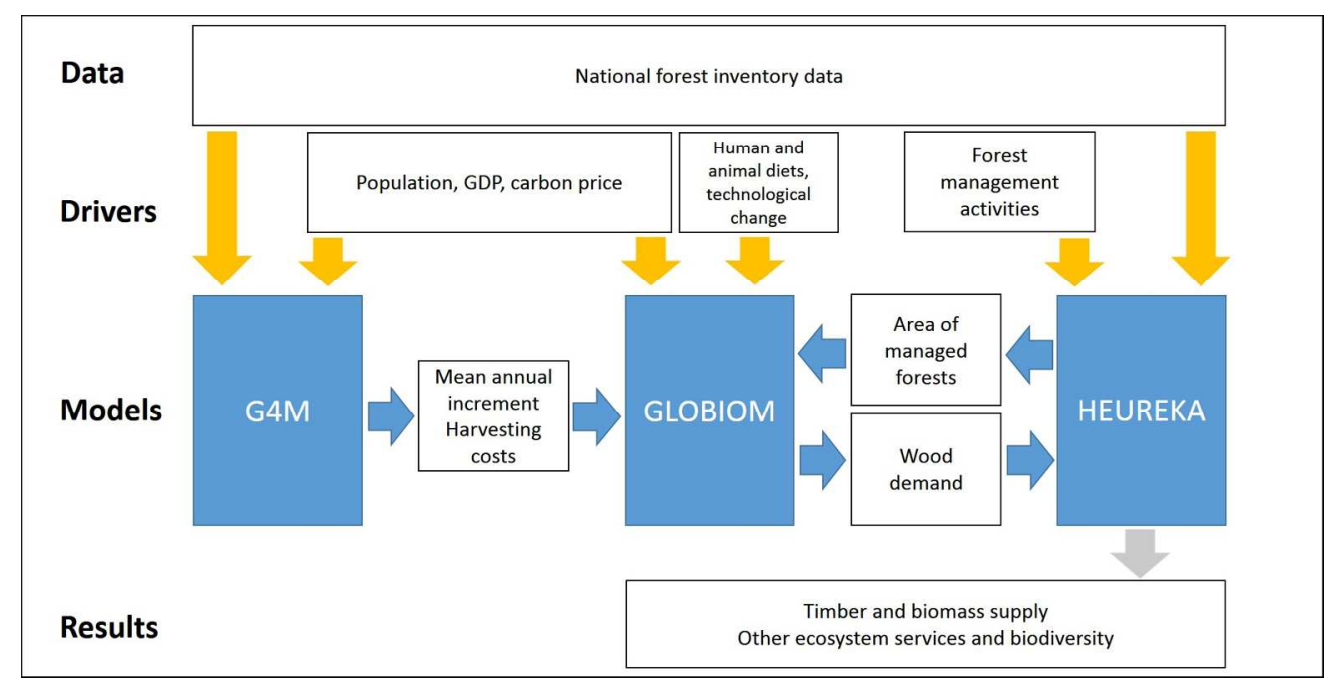

Figure 2. Schematic description of the model interlinkage.

$332 \times 168 \mathrm{~mm}(150 \times 150 \mathrm{DPI})$ 


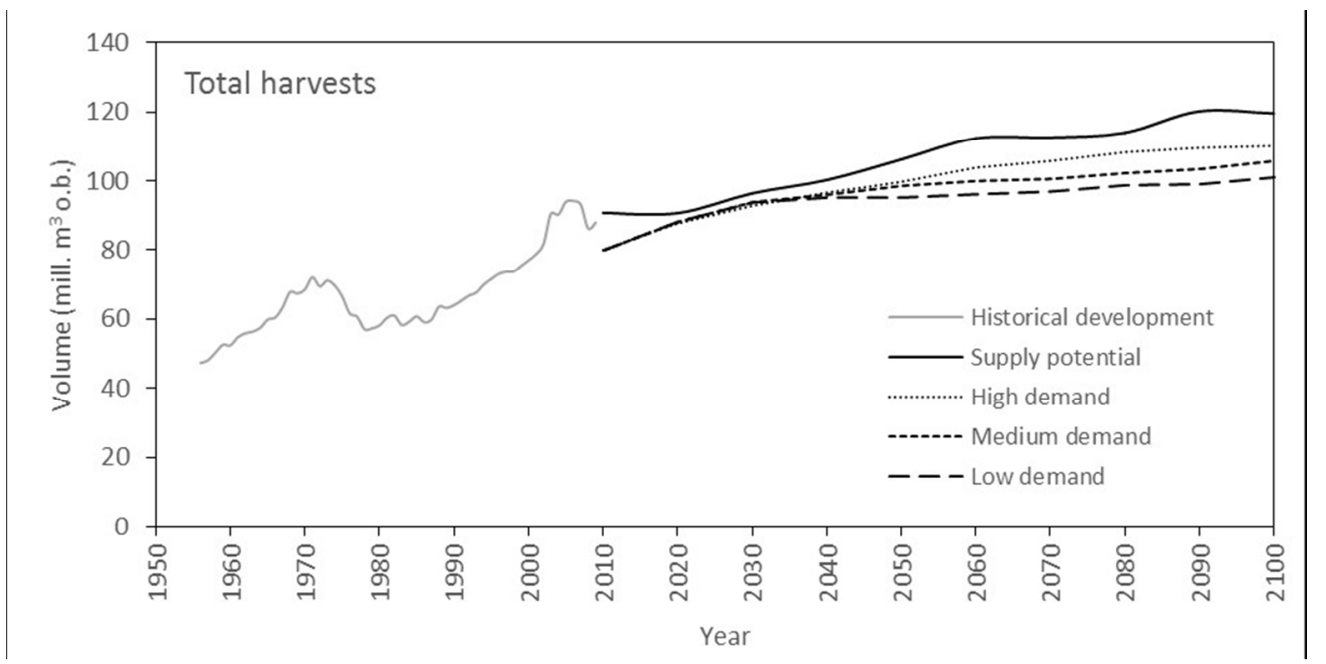

Figure 3. Total harvest of wood projected for Sweden for 2010-2100 in the supply scenario (Supply potential) and in the demand scenarios (High, Intermediate and Low demand), as well as the historical harvest development for 1956-2009 (SFA 2014).

$160 \times 80 \mathrm{~mm}(150 \times 150 \mathrm{DPI})$ 
a)

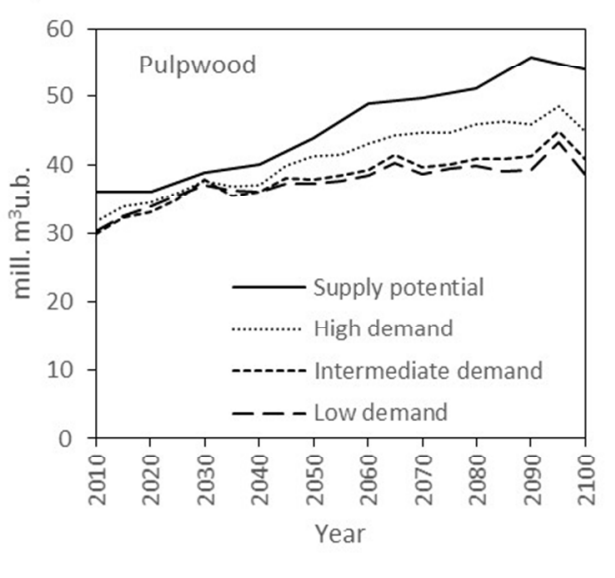

b)

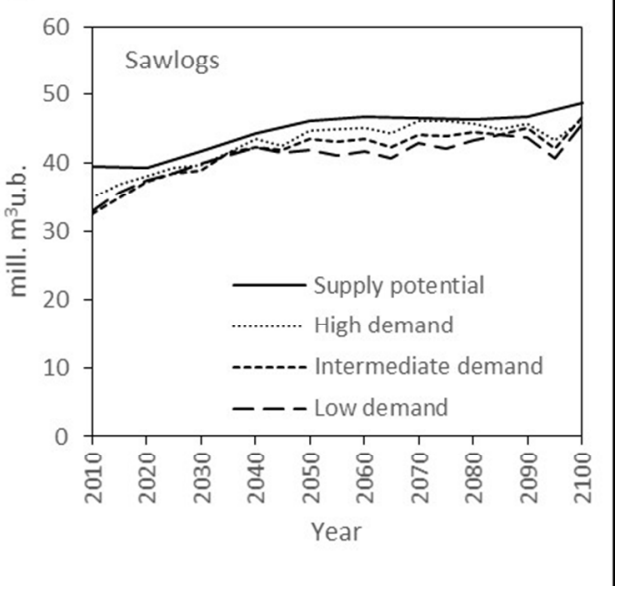

Figure 4. Volume of pulpwood and sawlogs harvested in the different scenarios. $160 \times 80 \mathrm{~mm}(150 \times 150 \mathrm{DPI})$ 


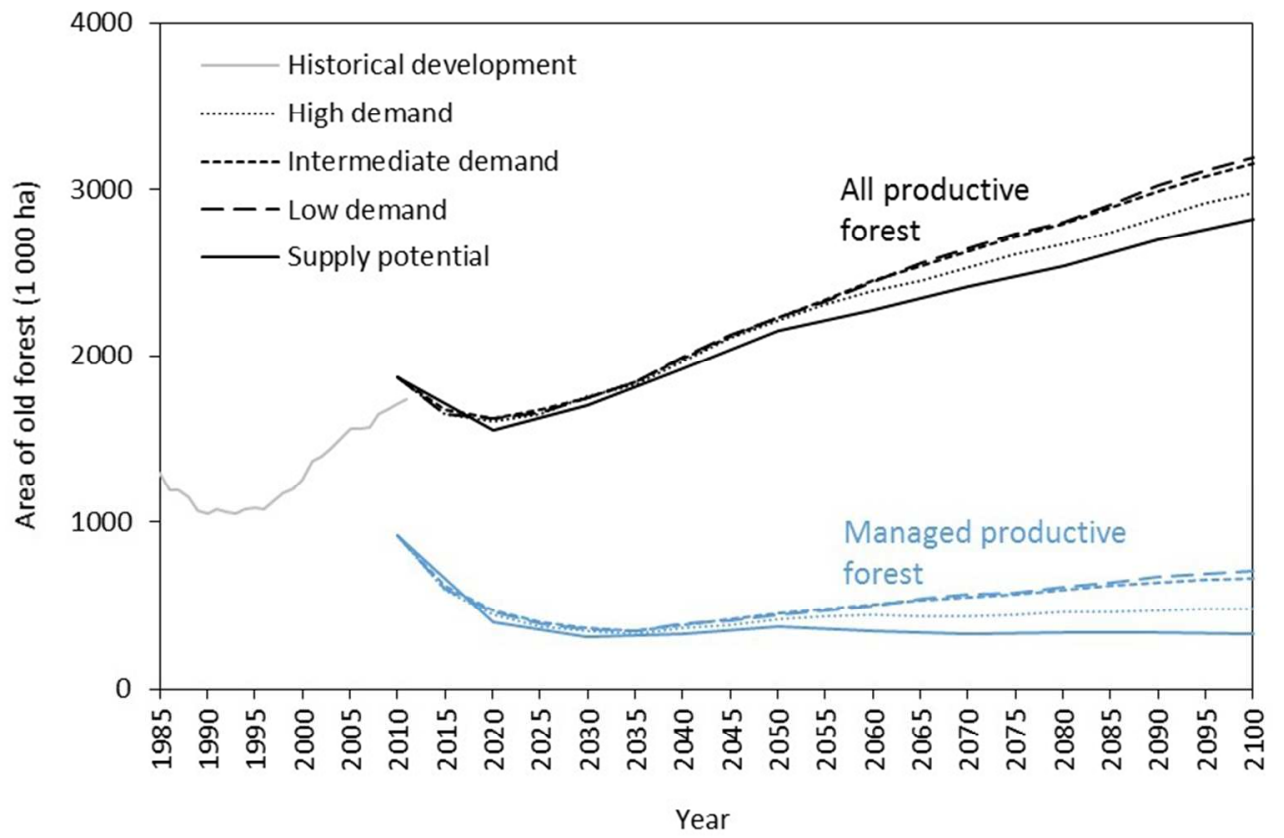

Figure 5. The development of old forest area in the supply and demand scenarios on all productive forest land and on the share of productive forest land managed for biomass production and the historical development on all productive forest land (Swedish NFI 2015).

$150 \times 100 \mathrm{~mm}(150 \times 150 \mathrm{DPI})$ 

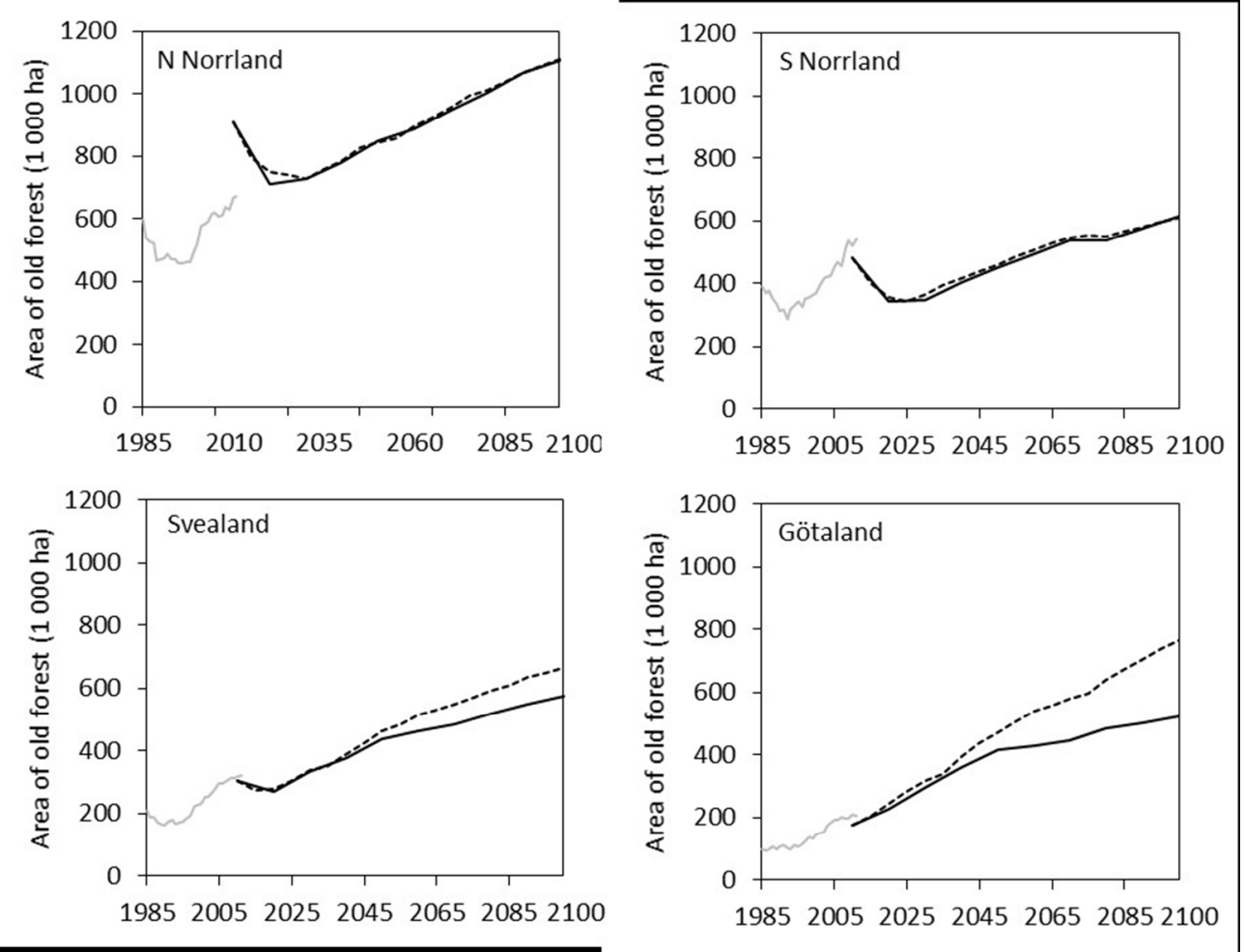

Figure 6. The development of old forest area on all productive forest land in the four regions of Sweden in the Supply potential and the Intermediate demand scenarios, and the historical development on all productive forest land in the regions (Swedish NFI 2015).

$157 \times 119 \mathrm{~mm}(150 \times 150 \mathrm{DPI})$ 


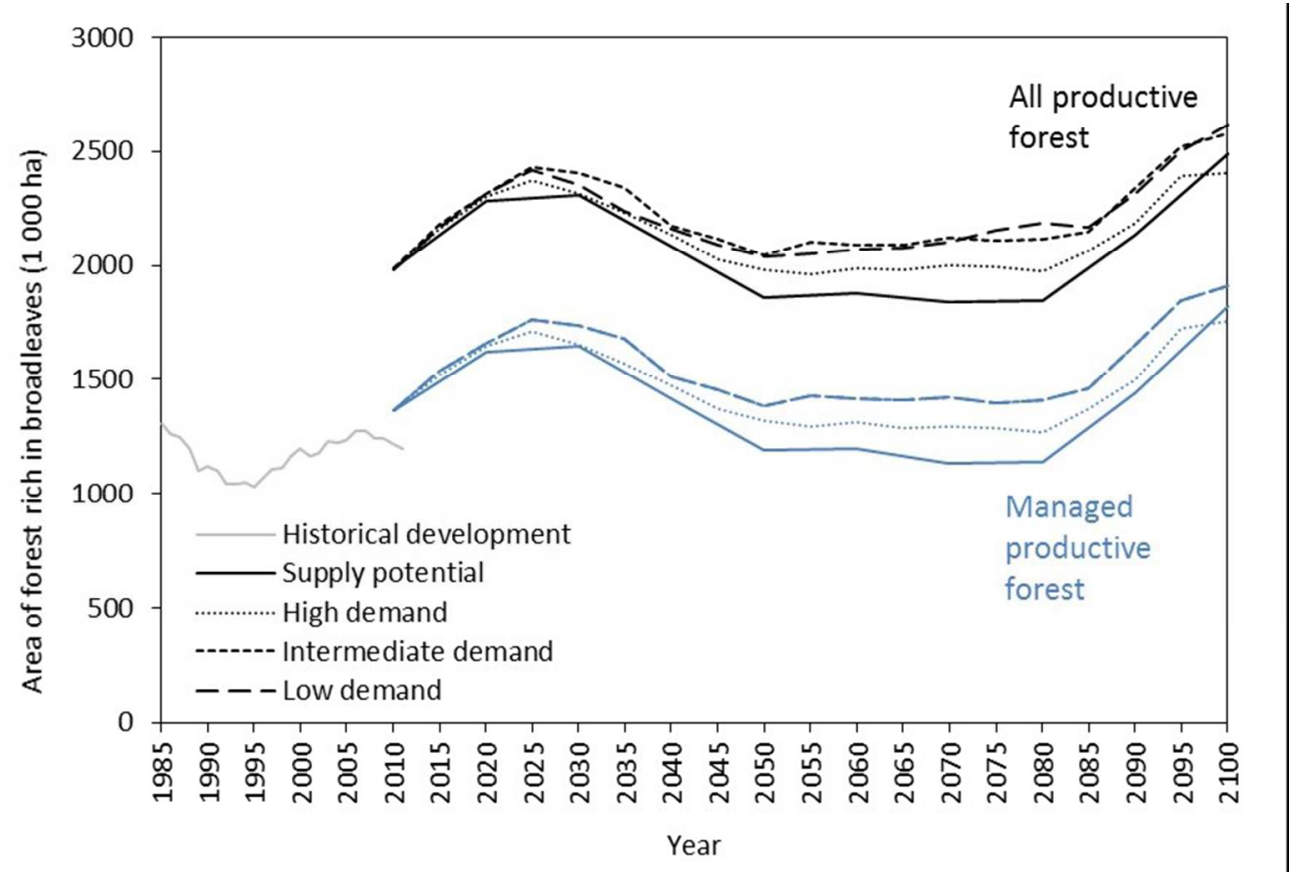

Figure 7. Development of the area of old forest rich in broadleaves in the different supply and demand scenarios and the historical development for managed productive forest (Swedish NFI 2015).

$$
150 \times 100 \mathrm{~mm}(150 \times 150 \mathrm{DPI})
$$

